\title{
Physical and chemical properties of copper-zinc galvanic sludge in the process of thermal treatment
}

\author{
Vasylii Larin ${ }^{\mathrm{a}}$, Vita Datsenko ${ }^{\mathrm{b}}$, Lilya Egorova ${ }^{\mathrm{c}}$, Inna Hraivoronskaia ${ }^{\mathrm{d}}$, Tetiana Herasymchuk ${ }^{\mathrm{e}}$ \\ ${ }^{a}$ Scientific Research Institute of Chemistry, Vasylii Karazin National University of Kharkiv, \\ Maidan Svobody, 4, Kharkiv 61077, Ukraine \\ ${ }_{b, c, d, e}$ National Automobile and Highway Universit of Kharkiv, Yaroslava Mudrogo, 25, Kharkiv \\ 61002, Ukraine \\ dacenkovita14@gmail.com
}

Keywords: dissolution, copper, zinc, galvanic sludge, model medium, thermal treatment.

This academic work is focused on the study of physical-chemical patterns of copper-zinc galvanic sludge dissolution prior to and after thermal treatment in model solutions with a given $\mathrm{pH}$. They show that all types of galvanic sludge eluates prior to and after thermal treatment are characterized by rather high concentrations of $\mathrm{Cu}^{2+}$ and $\mathrm{Zn}^{2+}$ ions. In acid eluates, the contents of zinc and copper ions are comparable. In extracts of distilled water and buffer solution, $\mathrm{Zn}^{2+}$ concentrations are higher than those of $\mathrm{Cu}^{2+}$. It has been established that the thermal treatment of galvanic sludge does not contribute to the retention of heavy metal ions in the sample. The intensity of dissolution of copper and zinc from galvanic sludge after thermal treatment increases with decreasing $\mathrm{pH}$. It is proved that copper-zinc galvanic sludge presents a potential water-migration hazard.

\section{Introduction}

Currently, one of the reserves for expanding the raw material base of the production sector is the electroplating industry waste, namely galvanic sludge (GS). This waste is generated at machine-building and instrument-making plants at treatment of electrode position sewage and the cleaning of electroplating chambers. The problem of galvanic sludge utilization generated at these enterprises is of paramount importance, since they are expensive, scarce and toxic [1].
Galvanic sludge contains a significant number of valuable components that can be used as a source of secondary resources. The components extracted from GS are used for the manufacture of alloys, pigment-fillers, fertilizers, glass products, glazes, polyoxide catalysts, and road pavements [2, 3].

However, galvanic sludge is a waste of hazard class 2-3 [4] and poses a serious threat to the environment. Its danger stems from the presence of heavy metal ions with highly toxic, carcinogenic and mutagenic effects on living organisms. Therefore, when disposing GS in 
combination with obtaining valuable substances and materials, the environmental safety of the latter should be taken into account.

Domestic and foreign periodicals contain publications devoted to the study of the problem regarding the effect of industrial waste (IW) on the environment as well as public health [1-5]. The information provided by the above publications does not fully reflect the environmental performance of neutralized GS. Thereby, the findings provided in the respective research papers cannot be used for an objective assessment of the environmental safety of galvanic sludge.

Analyzing the methods of GS utilization from the view point of environmental impact, certain experts give priorities to technologies in which the thermal treatment is an essential element [6-8]. The authors of these papers note that when using low-temperature technologies for the disposal of sludge, a significant release of highly toxic compounds can occur in the environment.

Therefore, in the current context, a rational flow-sheet of waste disposal at industrial enterprises should contain a sound technology that is aimed not only at minimizing the generation of such waste, but also include an assessing its toxicity for recycling as secondary raw materials.

The object of this paper is to study the physical-chemical patterns of copper and zinc ions dissolution in the systems «GS- model environment». In furtherance of the target goal, research was carried out on thermal treatment of model copper-zinc galvanic sludge; the patterns of copper and zinc compounds dissolution in model solutions with a given $\mathrm{pH}$ were studied; potential environmental safety of model GS prior to and after thermal treatment was determined.

\section{Experimental part}

Electroplating copper-zinc sludge is a product of cleaning and neutralizing acidic wastewater from electroplating workshops, relying in their technologies on electrochemical dimensional etching of copper and its alloys. In practice, such wastes are most frequently a subject to disposal, although they can be used as useful components of raw mixes. The selected composition of model corresponds to the composition of sludges obtained by the neutralization reaction of spent pickling solutions after the technological operation of etching $\alpha$-brass at small enterprises in Kharkov [4].

To study the leaching of heavy metal ions (HM) from GS into the model media, metal ions of copper and zinc were selected. The selection of the above metals is associated with a high toxicity degree and a significant content of the latter in industrial GS [4].

Model GS was experimentally obtained as a result of neutralizing the sulfate copper-zinc solution with lime $1 \mathrm{M}$. X-ray phase analysis of 
GS samples was performed on a Siemens D500 powder diffractometer in copper radiation using a graphite monochromator. The full-profile diffractogram was measured in the angle interval of $5<2 \theta<80^{\circ}$ with a step of $0,02^{\circ}$ and the accumulation time of 40 seconds. The primary phase search was performed using the PDF-1 card file [4], after which the radiographs were calculated using the Rietveld method.

The elemental composition of the sample sediment according to electron probe microanalysis is, \%: $\mathrm{Cu}-25,46 ; \mathrm{Zn}-17,92$; $\mathrm{Ca}$ - 10,3; O - 33,74; S - 12,58. X-ray phase analysis of a model GS sample showed that its main phases are gypsum $\mathrm{CaSO}_{4} \cdot 2 \mathrm{H}_{2} \mathrm{O}$, gunningite $\quad \mathrm{ZnSO}_{4} \cdot \mathrm{H}_{2} \mathrm{O}, \quad$ bassanite $\mathrm{CaSO}_{4} \cdot 0,5 \mathrm{H}_{2} \mathrm{O}, \quad$ ktenasite $(\mathrm{ZnCu})_{5}$ $\left(\mathrm{SO}_{4}\right)_{4}(\mathrm{OH})_{12}\left(\mathrm{H}_{2} \mathrm{O}\right)_{12}$, antlerite $\mathrm{Cu}_{3}(\mathrm{OH})_{4}\left(\mathrm{SO}_{4}\right)$, goslarite $\mathrm{ZnSO}_{4} \cdot 7 \mathrm{H}_{2} \mathrm{O}$ and namuwite $\left(\mathrm{Zn}_{3,2} \mathrm{Cu}_{0,8}\right)\left(\mathrm{SO}_{4}\right)(\mathrm{OH})_{6} \cdot 4 \mathrm{H}_{2} \mathrm{O}$.

To perform the thermal treatment of sludge, a SNOL-7.2/1100 muffle furnace with a digital thermostat was used (the heating rate is $10^{\circ} \mathrm{C} / \mathrm{min}$ in the range from 100 to $1000^{\circ} \mathrm{C}$ ). The analyzed samples $(10 \mathrm{~g})$ were subjected to thermal treatment in a loss-on-drying oven and a muffle furnace at temperatures, ${ }^{\circ} \mathrm{C}: 100,200$, $300,400,500,600,700,800,900,1000$. The duration of thermal treatment at each temperature range constituted 3 hours. The mass loss of the GS sample during thermal treatment begins at temperatures below $100{ }^{\circ} \mathrm{C}$, and ends at $700{ }^{\circ} \mathrm{C}$. The mass loss occurs due to the removal of hygroscopic and crystallization moisture in chemical compounds and decomposition of $\mathrm{Cu}(\mathrm{II})$ and $\mathrm{Zn}$ (II) sulfates. Chemical and spectral analysis of GS after calcination did not reveal the volatilization of copper and zinc ions from the latter.

Using X-ray phase analysis, samples of heat-treated GS were identified as a mechanical mixture of the phases of Anhydrite $\mathrm{Na}_{2} \mathrm{SO}_{4}$, oxysulfate $\quad \mathrm{Zn}_{3} \mathrm{O}\left(\mathrm{SO}_{4}\right)_{2}, \quad \mathrm{Cu}_{2} \mathrm{OSO}_{4}$, $\mathrm{Zn}\left(\mathrm{SO}_{4}\right)\left(\mathrm{H}_{2} \mathrm{O}\right)_{6}, \quad \mathrm{CuO}, \quad$ and $\mathrm{Zn}_{3,2} \mathrm{Cu}_{0,8}\left(\mathrm{SO}_{4}\right)(\mathrm{OH})_{6}\left(\mathrm{H}_{2} \mathrm{O}\right)_{4}$. The occurrence of $\mathrm{Zn}_{3} \mathrm{O}\left(\mathrm{SO}_{4}\right)_{2}, \mathrm{Cu}_{2} \mathrm{OSO}_{4}$, and $\mathrm{CuO}$ phases in the heat-treated GS is explained by thermal decomposition of the corresponding untreated GS minerals, i.e. mainly Gunningite $\mathrm{ZnSO}_{4}$ $\mathrm{H}_{2} \mathrm{O}$, Goslarite $\mathrm{ZnSO}_{4} \quad 7 \mathrm{H}_{2} \mathrm{O}$, and Antlerite $\mathrm{Cu}_{3}(\mathrm{OH})_{4}\left(\mathrm{SO}_{4}\right)$.

Leaching of $\mathrm{Cu}^{2+}$ and $\mathrm{Zn}^{2+}$ from GS prior to and after the thermal treatment was performed using 3 extractants: distilled water $(\mathrm{pH}=6,8)$; ammonium acetate buffer solution $(\mathrm{pH}=4,8)$ and hydrochloric acid $(0,8 \mathrm{M} \mathrm{HCl})$ [4]. Prior to each research, GS was kept in a muffle furnace at a temperature of $100{ }^{\circ} \mathrm{C}$ with the objective of dehydration. Eluates were obtained by mixing the model GS with an extractant in the ratio of 1:10 (mass ratios taking into account the moisture content), followed by sludging and paper filtration. Determination of $\mathrm{Cu}^{2+}$ and $\mathrm{Zn}^{2+}$ concentrations in eluates was carried out in accordance with the method [4] after 1, 3, 7, 10, 20 and 30 days with a sludge 
aging in the respective extractant at a temperature of $20^{\circ} \mathrm{C}$.

The concentrations of $\mathrm{Cu}^{2+}$ and $\mathrm{Zn}^{2+}$ ions when leaching the latter from GS into the model medium were determined using the atomic absorption method on the «Saturn» spectrophotometer, when the wave length for zinc is $213,9 \mathrm{~nm}$, for copper is $324,8 \mathrm{~nm} ; J=10$ $\mathrm{mA}[4]$.

\section{Results and discussion}

Description of the system «GS - model environment». The results of experimental modeling of the «GS-model environment» system behavior are presented in Fig. 1-3. As the presented results show, all types of GS eluates, both prior to the thermal treatment and after it, are characterized by rather high concentrations of $\mathrm{Cu}^{2+}$ and $\mathrm{Zn}^{2+}$ ions.

The dissolution of GS is influenced by the properties of the liquid phase in contact with it (nature, concentration and $\mathrm{pH}$ solution) as well as the physical-chemical properties of the solid phase of GS propertys. It can be assumed that the Gunningite $\mathrm{ZnSO}_{4} \cdot \mathrm{H}_{2} \mathrm{O}$ and goslarite $\mathrm{ZnSO}_{4} \cdot 7 \mathrm{H}_{2} \mathrm{O}$, which have good solubility in water, forming part of the GS model prior to the thermal treatment, precondition the occurrence of $\mathrm{Zn}$ in the aqueous model solution. Antlerite $\mathrm{Cu}_{3}(\mathrm{OH})_{4}\left(\mathrm{SO}_{4}\right)$ is insoluble in water, but well soluble in acids, which explains the presence of copper in acid eluates. Hydrated double hydroxyl salts, namely Namuwite
$\left(\mathrm{Zn}_{3,2} \mathrm{Cu}_{0,8}\right)\left(\mathrm{SO}_{4}\right)(\mathrm{OH})_{6} \cdot 4 \mathrm{H}_{2} \mathrm{O}$ and Ktenasite $(\mathrm{ZnCu})_{5}\left(\mathrm{SO}_{4}\right)_{4}(\mathrm{OH})_{12}\left(\mathrm{H}_{2} \mathrm{O}\right)_{12}$, can determine the occurrence of the studied metals in acidic and acetate ammonium buffer eluates. This may be due to the fact that the hydroxides that form the basis of the respective minerals are well soluble in acids and alkalis.

For GS after thermal treatment, the interaction in the ${ }^{2} \mathrm{Cu}_{2} \mathrm{OSO}_{4}, \mathrm{Zn}_{3} \mathrm{O}\left(\mathrm{SO}_{4}\right)_{2}-$ $\mathrm{H}_{2} \mathrm{O}$ » system is accompanied by a transition to the solution of the respective $\mathrm{Cu}^{2+}$ and $\mathrm{Zn}^{2+}$ ions. $\mathrm{CuO}$ developed in $\mathrm{GS}$ after thermal treatment, which is practically insoluble in water, but has a high solubility in acids, therefore, preconditions the occurrence of $\mathrm{Cu}^{2+}$ ions in the $« \mathrm{CuO}-\mathrm{HCl} »$ system. The process of copper oxides dissolution involves the stage of hydroxylation of the oxide surface, which is performed through protonation or hydration with the development of ionic and molecular forms of the complexes in work [9] was shown.

The presence of HMs in the aqueous eluate characterizes their migration as well as biochemical activity and, consequently, their maximum adverse effect on both the environment and humans. For this purpose, the migration of zinc and copper ions from the model roasted and unroasted GS to the aquatic environment was studied. From the results obtained it can be seen (Figure 1) that the course of the solution profile of copper compounds from GS prior to and after thermal treatment is miscellaneous. 


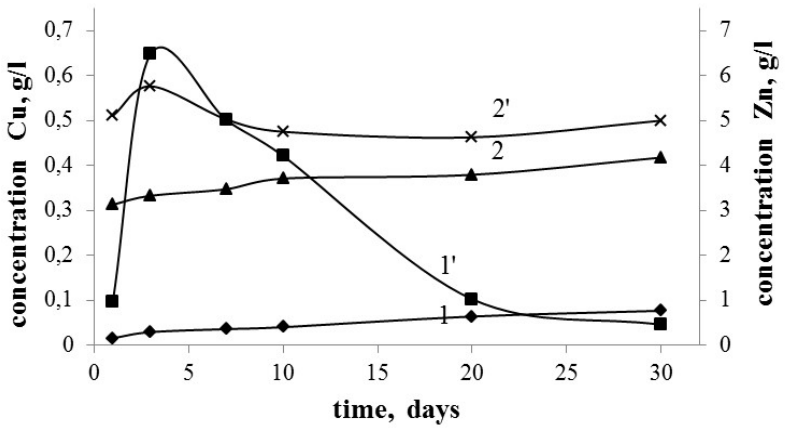

Figure 1. Dissolution of metal ions in distilled water: copper: 1 - before thermal treatment, $1^{\prime}$ - after thermal treatment;

zinc: 2 - prior to thermal treatment, $2^{\prime}-$ after thermal treatment

Prior to thermal treatment, during the first 7 days, the solution is saturated with $\mathrm{Cu}^{2+}$ ions (Figure 1, line 1). Prolonged galvanic sludge exposure to aquatic environment (30 days) leads to a slight increase in the concentration of copper ions in aqueous eluates. After the thermal treatment, the influx of copper ions from GS into the aqueous eluate is described by intense saturation and has an extreme character on the first day of the GS contact with the aqueous medium (Figure 1, line $\left.1^{\prime}\right)$. After 3 days, a sharp decrease in the dissolution of $\mathrm{Cu}^{2+}$ ions is observed. The decrease in the concentration of $\mathrm{Cu}^{2+}$ is due to the development of water-insoluble copper compounds, for instance, hydrated hydroxyl salts

$$
\begin{aligned}
4 \mathrm{Cu}^{2+}+\mathrm{SO}_{4}{ }^{2-}+8 \mathrm{H}_{2} \mathrm{O} & \rightarrow \mathrm{Cu}_{4}(\mathrm{OH})_{6} \mathrm{SO}_{4} \cdot 2 \mathrm{H}_{2} \mathrm{O} \downarrow \\
& +6 \mathrm{H}^{+} ;
\end{aligned}
$$

$$
\begin{aligned}
3 \mathrm{Cu}^{2+}+\mathrm{SO}_{4}{ }^{2-}+6 \mathrm{H}_{2} \mathrm{O} & \rightarrow \mathrm{Cu}_{3}(\mathrm{OH})_{4} \mathrm{SO}_{4} \cdot 2 \mathrm{H}_{2} \mathrm{O} \downarrow \\
+ & 4 \mathrm{H}^{+} .
\end{aligned}
$$

The presence of the above compounds does not contribute to the intensification of copper dissolution due to the lack of a catalytic effect and leads to a decrease in the concentration of free $\mathrm{Cu}^{2+}$ ions. With further exposure to the aquatic environment (after 20 days), the dissolution process stabilizes.

For zinc ions, dissolution processes from GS prior to and after the thermal treatment by means of aqueous eluates are qualitatively similar, having an ascending character (Figure 1, line $\left.2,2^{\prime}\right)$, which indicates that the processes are related. After the thermal treatment, the process of zinc dissolution from GS on the first day is similar to the process of copper dissolution (Figure 1, line $1^{\prime}$ and $2^{\prime}$ ), reflecting the similar extreme nature.

It should be noted that after the respective $\mathrm{Cu}^{2+}$ and $\mathrm{Zn}^{2+}$ ions are transferred from GS to the solution, both prior to and after the thermal treatment, $\mathrm{pH}$ decreases from 6,8 to 6,2 . Thus, the system $\left\langle\mathrm{Cu}_{2} \mathrm{OSO}_{4}-\mathrm{H}_{2} \mathrm{O} »\right.$ is described by the reaction equation

$$
\begin{aligned}
3 \mathrm{Cu}_{2} \mathrm{OSO}_{4} & +4 \mathrm{H}_{2} \mathrm{O}=\mathrm{Cu}_{4}(\mathrm{OH})_{6} \mathrm{SO}_{4} \cdot \mathrm{H}_{2} \mathrm{O} \downarrow+ \\
& +\mathrm{Cu}^{2+}+2 \mathrm{SO}_{4}{ }^{2-} .
\end{aligned}
$$

Therefore, the above-mentioned raise in the acidity of the medium may be due to the presence of $\mathrm{Cu}^{2+}$ cations in the solution, which are hydrolyzed with decreasing $\mathrm{pH}$ of the solution medium. 
Studies have been carried out on the ionization of $\mathrm{Zn}^{2+}$ and $\mathrm{Cu}^{2+}$ ions from the GS under study to ammonium acetate buffer aluminate (Figure 2).

The dependences of $\mathrm{Cu}^{2+}$ and $\mathrm{Zn}^{2+}$ dissolution from GS prior to thermal treatment by means of buffer eluates are qualitatively similar, having an ascending character (Figure 2, line 1, 2), which reflects the identity of the processes. The process of metal compounds dissolution from GS takes place throughout the duration of the experiment. Exposure of the heat-treated GS samples in ammonium acetate buffer solution indicates that the ionization of metal ions from the structure of such samples is higher than that from the unroasted GS (Figure 2, line 1', 2').

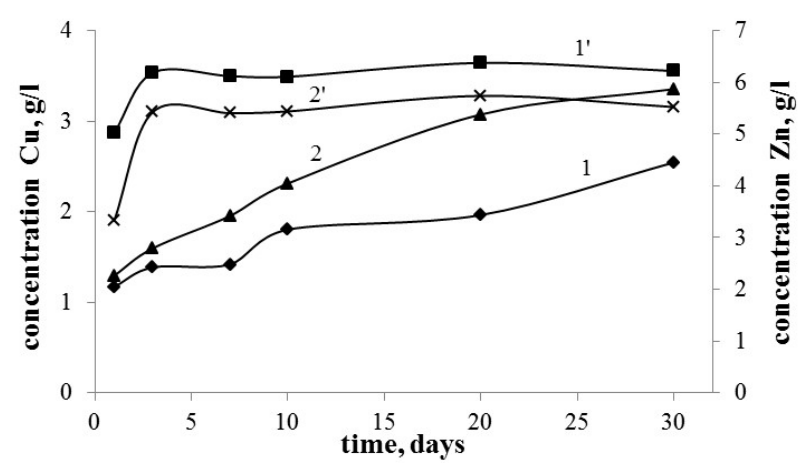

Figure 2. Dissolution of metal ions in ammonium acetate buffer solution:

copper: 1 - prior to thermal treatment, $1^{\prime}$ - after thermal treatment;

zinc: 2 -prior to thermal treatment, $2^{\prime}$ after thermal treatment

The dynamics of copper and zinc compounds dissolution from GS after the thermal treatment for 3 days in ammonium acetate buffer solution (Figure 2, line 1', 2') is similar to the processes in aqueous eluates (Figure 1, line 1', 2' ). Extremums are pronounced on the curves, which testify to the intensive dissolution of metal ions during 3 days. A decrease in their content, both in aqueous and in buffer eluates, was observed on day 3. Prolonged galvanic sludge exposure to aqueous and buffer media (30 days) does not lead to a significant increase in the concentrations of $\mathrm{Cu}^{2+}$ and $\mathrm{Zn}^{2+}$ ions in the respective eluates. The nature of the obtained dependences is explained, first of all, by the kinetic features of the process. On the first day, metal ions migrate from the surface layers of GS sample as a result of exposure to the media. Consequently, the metal ions are transformed into soluble forms and dissolve. Further, the migration process is significantly slowed down, which is associated with diffusion hindrance in the extraction of metal ions from the structure of GS sample.

The solvency of $\mathrm{HM}$ in $0,8 \mathrm{M} \mathrm{HCl}$ was investigated (Figure 3). The ionization of $\mathrm{Cu}^{2+}$ and $\mathrm{Zn}^{2+}$ ions from the structure of GS samples to acidic eluates is significantly higher than that to aqueous and ammonium acetate, which describes the total content of elements that can become mobile. The identical course of the dissolution curves both prior to (Figure 3, line 1,2) and after (Figure 3, line 1', 2') the thermal treatment indicates that the processes are 
related. The intake of copper and zinc ions from unroasted $\mathrm{GS}$ into $0,8 \mathrm{M} \mathrm{HCl}$ is characterized by saturation, having an extreme character on the first day (Figure 3, line 1, 2). On the 5th day, after exposing GS to acid, a slowdown in the process of metal compounds dissolution and a further decrease in leaching of the latter is observed during a month period. The saturation of acid eluates with $\mathrm{Cu}^{2+}$ and $\mathrm{Zn}^{2+}$ ions from the structure of heat-treated GS samples occurs during 7 days for copper (Figure 3, line 1'), during 10 days for zinc (Figure 3, line 2').In the later period, there is a decrease in the process of metal ions dissolution and on the 20th day there is an increase in the ionization of the latter from GS.

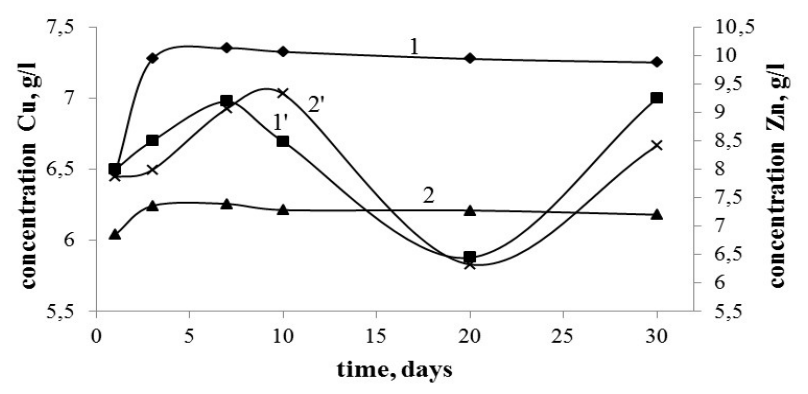

Figure 3. Dissolution of metal ions in acid: copper: 1 prior to thermal treatment, $1^{\prime}$ - after thermal treatment; zinc: 2 - before thermal treatment, $2^{\prime}$ - after thermal treatment

The rate of acid dissolution of metal compounds developed during calcination of GS largely depends on the nature of metal and is not determined by the transfer of ions into the solution, but by the reaction of their formation, i.e. the rate of breaking bonds in a solid body.
Therefore, the S-shaped character of the dissolution curves for copper and zinc from thermal-treated GS in acid eluates is probably due to diffusion branching of the active centers in the volume of their compounds [9]. There is no generally accepted mechanism for acid dissolution of metal oxides. Some researchers believe that the process is limited by the rate of metal cations escape from the solid phase. According to others, the process is limited by the entry of protons into the oxide phase. At the first stage, protons are adsorbed with the formation of $\mathrm{OH}$ groups, and then hydrogen atoms diffuse into the oxide phase, which leads to the recovery of deeper layers. Slow diffusion of hydrogen atoms preconditions the concentration polarization in the solid phase [9].

In acid eluates, the content of zinc and copper ions is comparable, unlike distilled water and buffer solution, in which $\mathrm{Zn}^{2+}$ concentrations are higher than $\mathrm{Cu}^{2+}$. When comparing the dynamics of dissolution from GS prior to and after thermal treatment separately for copper (Figure 3, line 1, 1') and for zinc (Figure 3, line 2, 2'), differences are observed. In the eluates from the unroasted GS, the concentrations of $\mathrm{Cu}^{2+}$ and $\mathrm{Zn}^{2+}$ ions in distilled water and the buffer solution are lower than those from the calcined ones. In acidic eluates for copper, the ratio of the excess of the concentration of $\mathrm{Cu}^{2+}$ ions from unroasted GS over the concentration of $\mathrm{Cu}^{2+}$ ions from the calcined one is insignificant and constitues 1,0. 
For zinc, the ratio of exceeding the transition of $\mathrm{Zn}^{2+}$ ions from thermal-treated GS to acid eluates is higher than that from the untreated one and constitutes 1,3. For instance, according to the authors of work [9], by increasing the dissolution rate, some $3 \mathrm{~d}$ metal oxides can be expanded into series: $\mathrm{NiO}<\mathrm{Fe}_{2} \mathrm{O}_{3}<\mathrm{CuO}$, $\mathrm{CoO}$, $\mathrm{FeO}<\mathrm{ZnO}, \mathrm{CdO}$. Thus, this suggests that the dissolution process is determined by the different solubility of metal compounds and primarily depends on the individual physical and chemical properties of the latter.

It should be noted that thermal treatment of GS does not always contribute to the retention of metal ions in the sample. The intensity of dissolution from GS after thermal treatment, both for copper and zinc in water and buffer solution, is below than in acid. Furthermore, the data of HMs dissolution from thermal-treated GS compared with GS, which did not undergo thermal treatment, have an ambiguous description. The ratio of exceeding the dissolution of metal ions (30 days) from unroasted GS over the same process from GS after thermal treatment of the latter in aqueous eluates is 1,7 for copper, for zinc is 0,8 ; in ammonium acetate eluates for copper is 0,7 , for zinc is 1,0 ; in acidic eluates for copper is 1,0 , for zinc is 1,3 . The ambiguity of interpretation of the data for dissolving copper and zinc from thermal-treated GS compared to untreated GS is explained by the dependence of the chemical properties of the compounds of these elements on $\mathrm{pH}$ of the solution in contact with them.

According to experimental data, the dissolution of copper and zinc in the «GS-model environment» system is primarily determined by the chemical composition of GS, as well as the chemical properties of the elements proper, which determine the nature of the interaction and the bond strength of the elements in GS.

The impact of galvanic sludge heavy metals on the environment. Currently, hygienic standards [4] of the content of the most hazardous elements in water have been developed. The potential water-migration hazard of the studied GS is characterized by comparing the maximum level of the actual content of galvanic sludge heavy metals in water and buffer extracts with their maximum allowable concentrations for water bodies $\left(\mathrm{MAC}_{\mathrm{w}}\right)$. The criterion of environmental pollution is the ratio of exceeding the standards $\left(\mathrm{MAC}_{\mathrm{w}}(\mathrm{Cu})=1,0 \mathrm{mg} / \mathrm{l} ; \operatorname{MAC}_{\mathrm{w}}(\mathrm{Zn})=1,0\right.$ $\mathrm{mg} / \mathrm{l}$ ) [4]. The results of the comparative analysis showed that in all eluates, the concentrations of $\mathrm{Cu}^{2+}$ and $\mathrm{Zn}^{2+}$ ions significantly exceed their MAC values for drinking and household water. It should also be noted that in copper-zinc sludge, both before thermal treatment and after it, $\mathrm{Zn}^{2+}$ ions reveal an increased water-migration activity as compared to $\mathrm{Cu}^{2+}$ ions in neutral $(\mathrm{pH}=6,8)$ and in dilute acidic $(\mathrm{pH}=5,1)$ environments. Thus, the ratio of exceeding the concentration of $\mathrm{Zn}^{2+}$ 
ions over $\mathrm{Cu}^{2+}$ ions in water eluate is 54 , and in ammonium acetate buffer is 2 . This indicates a lower copper mobility in the studied GS compared to zinc. Consequently, of the two competing doubly charged cations, the $\mathrm{Zn}^{2+}$ cations will make a greater contribution to the negative effect on the environment.

It is obvious that the studied copper-zinc GS possesses a potential water-migration hazard and cannot be considered environmentally friendly with regards to the environment. Atmospheric precipitation acts as the main factor contributing to the transfer of part of the immobile forms of copper and zinc in GS to the migration-active state.

\section{Conclusions}

Study of processes of heavy metals dissolution in the systems «GSH - model environment» has revealed that these processes are primarily determined by the chemical composition of GS, as well as the chemical properties of the elements' ions, which determine the nature of the interaction and the bond strength of the elements in GS.

The qualitative and quantitative composition of the model copper-zinc GS prior to and after thermal treatment has been established.

Studies on thermal treatment of model copper-zinc GS made it possible to establish that the sludge mass loss during thermal treatment starts at a temperature below $100{ }^{\circ} \mathrm{C}$ and ends at $700^{\circ} \mathrm{C}$. A stable state of sediment is achieved during the first hour of thermal treatment.

The study of physical-chemical patterns of copper and zinc ions dissolutionin the «GSmodel environment» systems showed that all types of eluates from GS both prior to thermal treatment and after it are characterized by rather high concentrations of $\mathrm{Cu}^{2+}$ and $\mathrm{Zn}^{2+}$ ions. In acid eluates, the content of zinc and copper ions are comparable. In aluminates of distilled water and buffer solution, $\mathrm{Zn}^{2+}$ concentrations are higher than those of $\mathrm{Cu}^{2+}$.

The comparison of dissolution dynamics from GS prior to and after thermal treatment separately for copper and zinc showed that in aluminates from unroasted GS the concentration of $\mathrm{Cu}^{2+}$ and $\mathrm{Zn}^{2+}$ ions in distilled water and buffer solution is lower than from calcined GS. In acidic eluates for copper, the ratio of the excess of $\mathrm{Cu}^{2+}$ ions concentration from unroasted GS over the concentration of $\mathrm{Cu}^{2+}$ ions from the calcined GS is 1,0. For zinc, the ratio of exceeding the transition of $\mathrm{Zn}^{2+}$ ions from thermal-treated GS to acidic eluates is 1,3 .

Thermal treatment of GS does not contribute to the retention of HMs ions in the sample. The intensity of dissolution from GS after thermal treatment, both for copper and zinc in water and buffer solution, is higher than in acid. The ratio of exceeding the dissolution of metal ions (30 days) from unroasted GS over the same process from GS after heat treatment 
of the latter in aqueous eluates is 1,7 for copper, for zinc is 0,8 ; in ammonium acetate eluates for copper is 0,7 , for zinc is 1,0 ; in acidic eluates for copper is 1,0 , for zinc is 1,3 .

Potential environmental hazards of GS for the environment are identified. The ratio of exceeding the concentration of copper and zinc in model eluates compared to their MAC for water bodies proves that copper-zinc GS presents a potential water-migration hazard.

The results obtained supplement the database on toxicity of IW and can be used for GS treatment.

\section{References}

[1] Pal M. The Complete Book on Waste Treatment Technologies. Delhi, India: Niir Project Consultancy Services; 2015, pp.556.

[2] Zhang Yu., Peixin Shi, Lijuan Ch., Qiang T. Utilization of Electroplating Sludge as Subgrade Backfill Materials: Mechanical and Environmental Risk Evaluation. Advances in Civil Engineering 2018;Article ID 4891418:925-930.

[3] Zhang M., Chen C., Mao L., Wu Q. Use of electroplating sludge in production of fired clay bricks: characterization and environmental risk evaluation. Construction and Building Materials;159:27-36.

[4] Datsenko V., Khimenko N., Egorova L., Svishchova Ya., Dubyna O., Budvytska O., Lyubymova N., Pasternak V., Pusik L. Construction of the algorithm for assessing the environmental safety of galvanic sludges. Eastern-European Journal of Enterprise Technologies 2019;6(10(102)):42-48. doi: 10.15587/1729-4061.2019.188251.

[5] Orescanin V., Durgo K., Mikelic I.L., Halkijevic I., Kuspilic M. Toxicity assessment of untreated/treated electroplating sludge using human and plant bioassay. Journal of environmental science and health. Part A, Toxic/hazardous substances \& environmental engineering 2018;53(10):925-930. doi: 10.1080/10934529.2018.1462911.

[6] Pawlak-Kruczek H.,Wnukowski M., Krochmalny K., KowalM., Baranowski M., Zgóra J., Czerep M., Ostrycharczyk M., Niedzwiecki L. The Staged Thermal Conversion of Sewage Sludge in the Presence of Oxygen. J. Energy Resour. Technol 2019;141(7):070701070701-8. doi: 10.1115/1.4042822

[7] Surzhko O.A., Epishin V.V., Okovitaya K.O. Termoobrabotka shlamov galvanicheskih proizvodstv $\mathrm{i}$ ispolzovanie ih $\mathrm{v}$ proizvodstve stroitelnyh materialov. Aktualnye problemy gumanitarnyh i estestvennyh nauk 2015;7(4):176-180.

[8] Krstić I., Zec S., Lazarević V., Stanisavljević M., Golubović T. Use of Sintering to Immobilize Toxic Metals Present in Galvanic Sludge into a Stabile GlassCeramic Structure. Science of Sintering 2018;50:139-147. doi: 10.2298/SOS1802139K

[9] Linko I.V., Kulikov A.B., Venskovskij N.U., Rudnickaya O.B., Lobanov N.L., Burvikova Yu.L. Vzaimodejstvie dolerofanitaCu $\mathrm{CuSO}_{4}$ s vodoj. Zhurnal neorganicheskoj himii 2002;47(11):1892-1895. 